\title{
POUND OF FLESH? DEBT CONTRACT STRICTNESS AND FAMILY FIRMS
}

\author{
David Hillier ${ }^{\wedge}$ \\ Strathclyde Business School, University of Strathclyde \\ 130 Rottenrow, Glasgow, G4 0GE, United Kingdom \\ david.hillier@strath.ac.uk \\ Beatriz Martínez \\ Management School, University of Liverpool \\ Chatham, Liverpool, L69 7ZH, United Kingdom \\ Tel. +3460475756 \\ B.Martinez-Garcia@liverpool.ac.uk \\ Pankaj C. Patel ${ }^{*}$ \\ Management and Operations Department \\ Villanova School of Business, Villanova University \\ Villanova, PA 19085 \\ Tel. +1-610-519-4317 \\ pankaj.patel@villanova.edu \\ Julio Pindado \\ Family Business Centre and IME, University of Salamanca \\ Campus Miguel de Unamuno, Salamanca, E37007, Spain \\ Tel. +34923294763 \\ pindado@usal.es \\ Leeds University Business School, University of Leeds \\ Moorland Rd, Leeds, LS6 1AN, United Kingdom \\ Tel. +441133432618 \\ j.pindado@lubs.leeds.ac.uk \\ Ignacio Requejo \\ Family Business Centre and IME, University of Salamanca \\ Campus Miguel de Unamuno, Salamanca, E37007, Spain \\ Tel. +34923294763 \\ irequejo@usal.es
}

Keywords: debt contracts, family firms, financial covenant slack, asset tangibility, R\&D.

Acknowledgements: For their valuable comments and suggestions, we are grateful to the Special Issue Editors, James J. Chrisman, Jess H. Chua, Isabelle Le Breton-Miller, Danny Miller, and Lloyd P. Steier, to two anonymous reviewers, and to the participants at the 2016 Theories of Family Enterprise (TOFE) Conference at the University of Alberta. We would also like to thank Emanuele Bajo, Viktoria-Sophie Bartsch, Laura Cabeza, Gary Cook, Marco Cucculelli, Wolfgang Drobetz, Chris Florackis, Zied Guedri, Christian Hilpert, Allan Hodgson, Sharon James, Malte Janzen, Félix J. López-Iturriaga, Moritz Lukas, Costas Milas, Nicole Ratzinger-Sakel, Luis Rodrigues, Henning Schröder, Bill Schulze, Alexander Szimayer, Zhenyu Wu, and Wenlong Yuan for suggestions.

We benefited from the comments of seminar participants at the 2014 International Accounting \& Finance Doctoral Symposium held in Trondheim (Norway), the 2016 UHH Finance Research Seminar at Universität Hamburg (Germany), and the 2016 Economics, Finance and Accounting Internal Seminar at the University of Liverpool Management School (United Kingdom).

We are also grateful to the Research Agency of the Spanish Government, DGI (Grant ECO2013-45615-P) for financial support. Beatriz Martínez acknowledges financial support from the Spanish Ministry of Education and Science. All errors are our own responsibility.

\footnotetext{
${ }^{\wedge}$ The authors are listed in alphabetical order by their last names.

${ }^{*}$ Corresponding author.
} 


\title{
POUND OF FLESH? DEBT CONTRACT STRICTNESS AND FAMILY FIRMS
}

\begin{abstract}
While past work finds support for both higher and lower cost of debt among family firms, whether lower shareholder-creditor agency conflicts in family firms translate into greater exante contracting efficiency (i.e., lower debt contract strictness) remains unexplored. Drawing on a shareholder-creditor agency framework and costly contracting theory, creditors, expecting firm value maximization rather than shareholder value maximization from family firms, may offer less strict debt contracts to increase contracting efficiency. We find in a sample of 716 publicly traded US firms (2001-2010) that family firms have less strict debt contracts, which are even less strict when family firms have higher asset tangibility. Although increases in R\&D investments could lead to more pronounced shareholder-creditor agency conflicts, given family firms' preferences for lower risk and growth, debt contract strictness among family firms is not positively associated with higher R\&D intensity.
\end{abstract}

\section{INTRODUCTION}

Corporate debt contracts include incentives and penalties coupled with monitoring mechanisms to limit asset substitution and overinvestment. The aspects of debt contract strictness range from dividend policies to restrictions on risk-shifting investments (Frankel, Seethamraju, \& Zach, 2008) and allow creditors to set parameters on resource allocations and maintain necessary liquidity. When a covenant is violated, control rights may shift to creditors, which allow them to intervene in corporate decisions. ${ }^{1}$

However, with increasing debt contract strictness, monitoring and enforcing debt covenants is costly. Based on the logic of contracting efficiency, when creditors perceive greater goal alignment with shareholders, debt contract strictness could be lowered to economize on contracting costs (Bolton \& Scharfstein, 1990; Frankel et al., 2008; Holthausen \& Leftwich, 1983). Tying the logic of contracting efficiency with the previous literature in family business research, debt related contracting costs could be lower or higher in family firms.

\footnotetext{
${ }^{1}$ At the root of shareholder-creditor agency conflict is the shareholders' incentive to promote investment in risky, high-returns projects. Expecting ex-post hazard of expropriation from shareholders, creditors demand a higher cost for debt and/or ex ante impose stricter debt contracts.
} 
On the one hand, interests of family firms align with those of the creditors. Due to their less diversified holdings ${ }^{2}$ family firms focus on firm value maximization instead of shareholder value maximization. Family firms have a lower preference for risky high-growth investments, are parsimonious and particularistic in allocating debt funds (Carney, 2005), are characterized by intentions for transgenerational continuity (Chrisman, Sharma, Steier, \& Chua, 2013), and are concerned about preserving reputation (Berrone, Cruz, Gomez-Mejia, \& Larraza-Kintana, 2010) and social capital (Arregle, Hitt, Sirmon, \& Very, 2007). On the other hand, due to their preference for private benefits of control (Burkart, Panunzi, \& Shleifer, 2003), they run the risk of entrenchment and nepotism (Friedman, Johnson, \& Mitton, 2003; Pérez-González, 2006) and their interests and goals may not align with those of creditors (Aslan \& Kumar, 2012).

Consistent with mixed theoretical propositions on shareholder-creditor agency costs in family firms, empirical findings are also mixed (Gottardo \& Moisello, 2016). Prior research shows that family firms have either a lower (Anderson, Mansi, \& Reeb, 2003) or similar (McConaughy, 1999) cost of debt compared to non-family firms. Conversely, illiquidity premium associated with family ownership (Aronoff, Ward, \& De Visscher, 1995) can increase the cost of capital. Reconciling the findings on positive, negative, and neutral effects of family influence on the cost of capital, Adams et al. (2004) propose that this cost is contingent on the degree of integrated goal-setting in family firms.

Given the competing theoretical arguments for lower and higher shareholder-creditor agency costs in family firms and mixed empirical evidence on ex-post contracting mechanisms (i.e., the cost of debt), the question of whether creditors still maintain stricter

\footnotetext{
${ }^{2}$ Note that we focus on publicly traded firms in the United States, which are likely to be less diversified. Although studies that investigate corporate control in developing and Asian countries (Bertrand, Johnson, Samphantharak, \& Schoar, 2008; Bertrand, Mehta, \& Mullainathan, 2000) highlight the pyramidal structures and tunneling practices of family firms in highly diversified conglomerates, publicly traded US firms are less diversified.
} 
debt covenants to monitor and control family firms or economize on monitoring and control costs with family firms remains to be answered.

We pose two additional questions. First, do creditors have even less strict debt contracts for family firms with higher asset tangibility? Less transparent family firms may be difficult to monitor, and asset tangibility helps to reduce information asymmetry and improve monitoring (Almeida \& Campello, 2007; Céspedes, González, \& Molina, 2010). Second, do creditors allow loss-averse family firms to make risky R\&D investments by not increasing debt contract strictness? If the lower shareholder-creditor agency costs expected in family firms are confirmed, both creditors and family firms could forbear to lower contracting frictions. Forbearance on the creditor's side can be assessed by a non-significant (significant) increase in debt contract strictness despite increases in R\&D in family (non-family) firms. ${ }^{3}$

The proposed framework makes the following two contributions. First, we contribute to financial economics research by identifying differences in contracting efficiency between family and non-family firms in corporate debt markets (Chava, Kumar, \& Warga, 2010; Gigler, Kanodia, Sapra, \& Venugopalan, 2009). Second, taking a contracting efficiency approach, we investigate the shareholder-creditor agency problem, which "has been largely absent [in] the finance literature about family firms" (Villalonga, Amit, Trujillo, \& Guzmán, 2015, p. 635).

\section{THEORETICAL DEVELOPMENT AND HYPOTHESES}

Family firm research has grown both theoretically and empirically over the past three decades (Gomez-Mejia, Cruz, Berrone, \& De Castro, 2011; Pindado \& Requejo, 2015). Agency theory has been central to family firm literature. Family firms have agency problems between shareholders and managers (Agency Problem 1), family shareholders and non-family

\footnotetext{
${ }^{3}$ If creditors expect lower asset substitution from family firms, they will not increase debt contract strictness despite higher R\&D in family firms, knowing that family firms with more efficient R\&D (Duran, Kammerlander, Van Essen, \& Zellweger, 2015) will not undertake such risk level that could lower firm value.
} 
shareholders (Agency Problem 2), shareholders and creditors (Agency Problem 3), and family shareholders and family non-shareholders (Agency Problem 4) (Villalonga et al., 2015). Agency Problem 3, proposed by Jensen and Meckling (1976), Myers (1977) and Smith and Warner (1979), is one of the less-discussed agency problems in the family firm literature (for exceptions, see Anderson et al., 2003; Boubakri \& Ghouma, 2010; Chua, Chrisman, Kellermanns, \& Wu, 2011).

Under the shareholder-creditor agency conflict (Agency Problem 3), risk-shifting concerns for creditors are asset substitution (i.e., managers accept higher-risk projects than anticipated by creditors) and overinvestment (i.e., managers invest in negative net present value projects). To curb expected shareholder-creditor agency costs, creditors significantly increase debt costs, reduce availability of credit, and/or impose stricter terms. However, both family business literature and normative agency theory suggest mixed arguments and evidence for family firms, so that their shareholder-creditor agency costs could be lower or higher.

Lower Shareholder-Creditor Agency Costs in Family Firms. The interests of family owners, who are concentrated shareholders with preference for firm value maximization over shareholder value maximization, may align with those of their creditors. Poutziouris (2002) finds that a majority of family firms avoid any source of finance that lowers family ownership and control, and Romano, Tanewski, and Smyrnios (2001) document the preference for debt and leasing arrangements of family owners who want to retain control of the business. Croci, Doukas, and Gonenc (2011); Wiwattanakantang (1999), Lee (2006), and King and Santor (2008), among others, show that family firms are more leveraged than nonfamily firms. Family firms are expected to be good stewards with debt and to be particularly diligent when complying with debt commitments (Corbetta \& Salvato, 2004). 
Past work also shows that family firms have a lower preference for risky, high-growth investments, including internationalization and acquisitions (for a review, see Gedajlovic, Carney, Chrisman, \& Kellermanns, 2012; Gomez-Mejia et al., 2011), and their long-term orientation could also improve debt management and capital structure (Casson, 1999). Family firms are less likely to increase asset substitution or overinvestment as such actions could jeopardize their own undiversified holdings, endanger their transgenerational intentions, and lower their reputational capital (Arregle et al., 2007; Berrone et al., 2010). Indirectly supporting this logic, Anderson et al. (2003) find that public family firms in the United States have a lower cost of debt.

Higher Shareholder-Creditor Agency Costs in Family Firms. Expecting opacity (Anderson, Duru, \& Reeb, 2009) and limited power in restructuring debt through negotiations with concentrated owners in a family firm (Hart \& Moore, 1994), creditors may construe shareholder-creditor agency costs to be greater and increase debt contract strictness. Examples of preference for private benefits of control over creditors' interests is evident in tunneling (e.g., Friedman et al., 2003; Jiang, Lee, \& Yue, 2010), entrenchment (e.g., Shyu \& Lee, 2009), and underinvestment practices (e.g., Jain \& Shao, 2014). Supporting this logic, family firms may have higher debt costs (Lin, Ma, Malatesta, \& Xuan, 2011), lower bond ratings, and higher bond-yield spreads (Boubakri \& Ghouma, 2010). Given the mixed evidence on the severity of shareholder-creditor agency costs in family firms, whether creditors prefer stricter or more lenient debt contracts when lending to this type of company remains an open question.

\section{Debt Contract Strictness and Family Firms}

Because asset substitution and overinvestment are less likely in family firms, creditors expect lower agency problems and prefer imposing less strict debt contracts to reduce contracting frictions (cf. David, O'Brien, \& Yoshikawa, 2008; Uzzi, 1999) for at least two reasons: (i) to 
increase alignment of incentives between family owners and creditors to maximize firm value (instead of shareholder value); and (ii) to avoid excessive monitoring costs, which make highly restrictive contracts less efficient in family firms.

Cautious and long-term oriented family firms with less diversified holdings are more conservative in resource allocations and have limited propensity to take risks (Gedajlovic et al., 2012). Despite lower power in debt restructuring in case of default and difficulty in monitoring due to higher opacity, debtors can reduce contracting and monitoring costs by relying on publicly available volatility indices (Demerjian, 2011). Because family firm conservatism induces lower volatility ratios and such ratios are observable, contracting costs should be lower for public family firms. Due to possible goal alignment between creditors and family owners (cf. Gigler et al., 2009) and as a result of better asset utilization and efficiency (Chen \& Hsu, 2009), family firms also have a comparative advantage over nonfamily firms in corporate debt markets.

With respect to lower need for monitoring, stricter debt contracts imply increased information gathering and higher monitoring costs (Emanuel, Wong, \& Wong, 2003; Holthausen, 1990). Contracting efficiency helps to "fill gaps, correct errors, and adapt more effectively to unanticipated disturbances" (Williamson, 1988: 570) to reduce frictions in contracting costs (Wang \& Williamson, 1998). As indication of lower need for monitoring, family firms are conservative in their reporting of financial performance (Ali, Chen, \& Radhakrishnan, 2007; Prencipe, Markarian, \& Pozza, 2008; Wang, 2006), exhibit timely loss recognition, and limit income smoothing (Prencipe et al., 2008). They also have higher earnings quality (Wang, 2006) and are more likely to warn about bad news (Ali et al., 2007). Concerns for family reputation lower incentives to compromise their standing in the corporate debt market, further reducing monitoring needs (Fehr, Brown, \& Zehnder, 2009). 
Counterintuitively, stricter debt contracts through greater collateralization, shorter maturity, and more financial covenants (e.g., times over net worth, current ratio, total debt, and interest coverage covenants) may not necessarily lower shareholder-creditor agency costs but may increase diffidence in family firm. Leverage reduces potential for future growth (Lang, Ofek, \& Stulz, 1996) and costly debt can create "overhang" from debt contract strictness that can lead family firms to underinvest.

Overall, compared to non-family firms (where managers have asymmetric incentives to underplay bad news, higher risk preference, and short-term orientation), in corporate debt markets, family firms may be perceived by creditors as having greater contracting efficiency. Therefore, we propose our first hypothesis.

Hypothesis 1. Debt contract strictness is lower in public family firms than in public non-family firms.

The strong correlation between performance of tangible assets and debt payments (Almeida \& Campello, 2007) could be an important signal for creditors, thereby contributing to increased contracting efficiency with family firms. Gompers (1995) states: "Tangible assets lower expected agency costs of inefficient continuation" (p. 1477). ${ }^{4}$ Contracting frictions may be significantly higher if the tangibility of assets is lower (Campello \& Giambona, 2011).

Increasing asset tangibility can make uncertainty or errors in assessment of shareholder-creditor agency costs more forgiving for less transparent family firms (cf. Bianco, Bontempi, Golinelli, \& Parigi, 2013). The more resources a firm has tied into tangible assets, the lower the information asymmetry is present in collateral valuation or debt restructuring. Tunneling behavior can be readily observed and firm opacity can be reduced with higher asset tangibility (cf. Almeida \& Campello, 2007; Graham, Li, \& Qiu, 2008; Whittred \& Zimmer, 1986). Wen, Rwegasira, and Bilderbeek (2002) find that asset

\footnotetext{
${ }^{4}$ Asset tangibility is measured as the ratio of tangible and fungible assets to total assets (Hall, 2012).
} 
uniqueness increases the need for greater tangibility. As family firms have unique and idiosyncratic resources that have evolved over generations (Sirmon \& Hitt, 2003), indirectly supporting Hall (2012) argument, higher asset tangibility could mitigate concerns from outsiders in evaluating and monitoring business activities.

Tangible assets also lend themselves more readily to particularism and personalism (Carney, 2005) as task, tool, and process relationships related with these assets are more clearly defined. Furthermore, family firms with higher asset tangibility rely less on branding and intellectual property and focus more on improving efficiency (McConaughy, Walker, Henderson, \& Mishra, 1998). Family firms have a higher input-output conversion ratio (Erbetta, Menozzi, Corbetta, \& Fraquelli, 2013; Lehmann, Warning, \& Weigand, 2004) and are more likely to revitalize, reconfigure, and realign their tangible resources (Sirmon \& Hitt, 2003). This capability is more appealing to creditors as continued vitality of tangible assets ensures smoother debt payments.

Overall, asset tangibility could increase contracting efficiency for both family and non-family firms, but more so for family firms. While non-family firms may allow for greater external oversight and for more inputs from external blockholders, greater tangibility may not lower agency costs as debt contracts may already account for lower opacity (Anderson et al., 2009; Bianco et al., 2013) in non-family firms. The higher cost of debt in non-family companies can act as a disciplining mechanism that lowers reliance on additional signals related to tangible assets. Furthermore, with limited idiosyncratic assets compared to family firms, the nature of assets could be more easily evaluated in non-family firms (Lin \& Shen, 2015), lowering debt contract concessions for these firms.

Based on these arguments and considering the previous reasoning leading to Hypothesis 1, we propose our second hypothesis.

Hypothesis 2. As asset tangibility increases, debt contract strictness becomes lower in public family firms than in public non-family firms. 
$\mathrm{R} \& \mathrm{D}$ expenditures have a longer time horizon to fruition and the associated returns are generally uncertain and skewed (Kothari, Laguerre, \& Leone, 2002). Given the mixed theoretical arguments and empirical findings on the preference of family firms for R\&D and the possibility of asset substitution associated with this type of investment, the question that remains is whether creditors should impose stricter debt covenants on public family firms in the face of increasing R\&D.

Expecting lower shareholder-creditor agency costs, creditors will forbear and not increase debt contract strictness even when family firms increase R\&D intensity due to lower risk of asset substitution. Knowing that R\&D investment exacerbates shareholder-creditor agency costs and lowers contracting efficiency, family firms will also forbear and not overinvest in R\&D. Creditors may infer that family firms will not increase firm risk significantly as such behavior can jeopardize the concentrated wealth of family owners. ${ }^{5} \mathrm{We}$ expect that creditors do not increase debt contract strictness when family firms increase R\&D to allow for "breathing room" for family firms to pursue innovation.

Forbearing Behavior from Creditors. Creditors focus on both facilitating ${ }^{6}$ and limiting violations of debt covenants through stricter contracts (Nini, Smith, \& Sufi, 2012). Not forbearing with family firms could impose economic and socioemotional costs and increase underinvestment, rendering a family firm at a competitive disadvantage. As family firms have long-term economic and non-economic wealth tied to the firm, the cost of forbearing may not be high for creditors (cf. Gómez-Mejía, Haynes, Núñez-Nickel, Jacobson, \& Moyano-Fuentes, 2007).

Forbearing Behavior from Family Firms. Family owners' concern for long-term performance and reputation allows creditors to trust that R\&D levels will not rise to asset

\footnotetext{
${ }^{5}$ The proposed forbearance is not related to relational debt types present in some countries (e.g., Japan; David et al., 2008; O'Brien, 2003) that allows creditors to facilitate R\&D through intensive monitoring.

${ }^{6}$ Such behavior results in necessary contractual slack for family firms to pursue opportunities so the underlying collateral assets are not jeopardized.
} 
substitution levels (cf. David et al., 2008). Restraint among family firms from pursuing growth opportunities that increase firm risk acts as an implicit check for creditors against such costs. Also, concern for reputation and the deep social ties of family firms create continuing relationships in the debt market, which lower moral hazard problems related to excessive R\&D. Greater volatility from higher R\&D investment is a concern for non-family firms because it exacerbates shareholder-creditor agency costs. Conversely, general diffidence toward (Bertrand et al., 2000; Block, 2012) and efficiency in (Duran et al., 2015) R\&D investment in family firms is sufficient to suggest to creditors that higher debt strictness with increasing R\&D will exacerbate contracting costs and jeopardize collateral assets in the long term. Based on this rationale, we propose our third hypothesis.

Hypothesis 3. As R\&D intensity increases, debt contract strictness does not increase in public family firms but does increase for public non-family firms.

\section{DATA AND METHODS}

\section{Data}

The initial data set consists of the US firms available in Compustat. We exclude regulated public utilities (SIC codes 4812, 4813, and 4911-4991), financial firms (SIC codes 60206799), foreign firms, firms listed as master limited partnerships, and firms with no available total assets or share price of less than $\$ 0.25$. Firms are classified into family and non-family using the information provided by Anderson et al. (2009) and Anderson, Reeb, and Zhao (2012). ${ }^{7}$ The time period covered ranges from 2001 to 2010. To control for survivorship bias, we allow firms to exit or enter the sample. The resulting sample is then merged with the December 2012 update of the Loan Pricing Corporation's DealScan Database, which includes historic data on the private loan agreements of 67,669 US companies collated from SEC filings (e.g., Dichev \& Skinner, 2002) or Loan Pricing Corporation's own data-gathering

\footnotetext{
${ }^{7}$ The percentage of family firms in the final sample is $27.68 \%$.
} 
process. ${ }^{8}$ When defining our debt contract strictness measure, we consider information on private covenants as opposed to just bond covenants because private loans dominate the market for corporate debt (e.g., Bagnoli, Liu, \& Watts, 2011) and private debt usually includes more restrictive covenants than public debt contracts (e.g., Mather \& Peirson, 2006).

We merge the databases using the ticker symbol and the company name to obtain a sample of 1,766 companies. We drop companies that do not have a coverage covenant in their debt contract or do not have at least six consecutive periods of data, which we need to compute the $\mathrm{m}_{2}$ statistic, necessary to test for the absence of second-order serial correlation in the first difference residuals when using the generalized method of moments. The final sample is an unbalanced panel of 716 companies (14,904 firm-quarter observations) from 2001 to 2010.

\section{Estimation Method}

Controlling for unobserved heterogeneity with the panel data methodology is important as it can affect contract strictness. In addition, we account for endogeneity, which stems from correlation between the error term and the explanatory variables. This correlation violates one of the main assumptions of the ordinary least squares method. To address this problem, we use an instrumental variables method adequate for a panel data setting: the system generalized method of moments, which embeds all other instrumental variables estimators as special cases.

Several specification tests are computed in the estimation process. First, we calculate the Hansen statistic, which tests for the lack of correlation between the instruments and the random disturbance. Second, we compute the $\mathrm{m}_{2}$ statistic, derived by Arellano and Bond (1991), to test for the lack of second order serial correlation in the first difference residuals.

\footnotetext{
${ }^{8}$ Panel B of Table 1 shows that debt contract components exhibit variation over time for the same company (see within component of the standard deviation of each dimension of the debt contract strictness index).
} 
Finally, we use three Wald tests to check for the joint significance of the reported coefficients $\left(\mathrm{z}_{1}\right)$, the temporal dummy variables $\left(\mathrm{z}_{2}\right)$, and the industry dummy variables $\left(\mathrm{z}_{3}\right)$.

\section{Dependent Variable}

We define an index of contract strictness using information from the DealScan database. The debt contract strictness index (DCSI) is based on eight debt contract features and ranges from zero to eight, with higher values of the index meaning a stricter contract. The eight debt contract features are the amount borrowed, whether the contract is secured, whether it is a revolver loan, the distribution method, the amount a borrower pays in basis points over LIBOR for each dollar drawn down, the number of lenders, maturity, and the number of covenants. ${ }^{9}$ We consider a contract to be stricter if the amount borrowed, the price of the loan, the number of lenders, and the number of covenants is higher than the sample median; if it is a secured or a syndicated loan; if it is not a revolver loan; or if the maturity of the loan is lower than the sample median. For each of these characteristics, we give the value of 1 if the characteristic is strict, and zero otherwise, and then we sum the eight values. Panels A and B of Table 1 detail the components of the index and their summary statistics, respectively.

\section{-----Insert Table 1 Here-----}

\section{Predictor Variables}

Panel $\mathrm{C}$ of Table 1 provides definitions of the family firm, moderator, and control variables. For a control, we use ROA, a measure of efficiency that can lower the DCSI. Larger firms require higher amount of financing than smaller firms, which makes the debt contract more complex and stricter. Given that larger firms need to be monitored more closely, we control for firm size. Higher debt levels can increase contract strictness, and dividends can signal lower probability of asset substitution as the firm may have fewer growth opportunities. We

\footnotetext{
${ }^{9}$ Previous literature on the determinants of firms' slack (e.g., Demiroglu \& James, 2010; El-Gazzar \& Pastena, 2010) supports the consideration of these characteristics to capture debt contract strictness.
} 
also control for volatility in performance. In addition, a higher market-to-book ratio can lead firms to prefer equity to debt financing. ${ }^{10}$ Finally, all models include time and industry dummies and the individual effect to control for unobserved heterogeneity $\left(\eta_{\mathrm{i}}\right){ }^{11}$

\section{Results}

Panel A of Table 2 presents the means, standard deviations, minimums, maximums, and correlation matrix of the variables used in the models. The variance inflation factors for all variables are below 5. Therefore, multicollinearity is less likely to affect our regression results.

-----Insert Table 2 Here-----

Table 2 also provides preliminary evidence on the differences between family and non-family firms regarding debt contract and firm characteristics. Panel B shows, as expected, that the strictness of the debt contract is lower for family firms (3.7272) than for non-family firms (3.9098). Also, the coverage covenant, which is the restriction imposed by the debtholder on a minimum coverage ratio, is less restrictive (lower values) for family firms (2.6504) than for non-family firms (2.8705). Consistent with prior family firm literature, Panel C shows that family firms have lower performance, size, risk and growth opportunities, and issue more debt than non-family firms.

\section{Tests for Hypotheses 1 and 2}

Table 3 presents the results of the regression analyses. Model 1 shows that family firms are negatively related to the DCSI $\left(\alpha_{2}=-0.024, p<0.01\right)$, which supports Hypothesis 1 . This estimate can be interpreted as family firms having a DCSI of $6.65 \%$ (i.e., [0.385- $(0.385-$

\footnotetext{
${ }^{10}$ These control variables are frequently used in capital structure research. For instance, the inclusion of ROA in the models enables us to capture pecking order patterns.

${ }^{11}$ Controlling for the individual effect is important as it captures the potential impact of personal collateral on contract strictness. Although we cannot measure family wealth, the propensity to use personal guarantees can be assumed constant over a short-time period. For instance, some family owners may be more prone than others to pledge their personal assets in negotiations with lenders. Such personal preferences are unlikely to change over time and hence are accounted for by the individual effect in the models.
} 
$0.024)] /(0.385-0.024)=0.0665)$ lower than non-family firms. ${ }^{12}$ In line with Hypothesis 2 , family firms with more tangible assets have a lower DCSI than that of non-family firms with more tangible assets (Model 2, $\gamma_{1}=-0.309, p<0.01$ ). Panel A of Figure 1 demonstrates that, as asset tangibility increases, DCSI of family firms decreases. Specifically, high-tangibility family (non-family) firms have a DCSI of 0.2845 (0.3526), indicating a $19.32 \%$ (i.e., $[0.2845-0.3526] / 0.3526=0.1932)$ lower DCSI for family firms than for non-family firms with comparable asset tangibility. ${ }^{13}$

\section{-----Insert Table 3 Here----- \\ -----Insert Figure 1 Here-----}

\section{Tests for Hypothesis 3}

Forbearing Behavior from Creditors. Hypothesis 3 proposes that, with increases in R\&D intensity, DCSI remains stable in family firms but increases in non-family firms (Model $3, \gamma_{2}=-0.633, p<0.01$ ). Panel B of Figure 1 supports the hypothesis; that is, as R\&D intensity increases, the DCSI of non-family firms also increases, but the DCSI of family firms remains unchanged. Therefore, the difference in the DCSI between family and non-family firms is higher when R\&D intensity increases. Specifically, the DCSI of high-R\&D intensity family (non-family) firms is 0.3624 (0.4019), indicating a $10.90 \%$ (i.e., [0.4019$0.3624] / 0.3624=0.1090$ ) higher DCSI for non-family firms than for family firms with comparable R\&D intensity.

Forbearing Behavior from Family Firms. Behavioral theory suggests that the distance from bankruptcy is a determinant of $\mathrm{R} \& \mathrm{D}$ investment and that companies limit risky investments when they are close to bankruptcy (e.g., Alessandri \& Pattit, 2014). To test for this possibility, we investigate the effect of coverage slack on R\&D intensity. Coverage slack

\footnotetext{
12 To compute the difference in the DCSI between family and non-family firms, we use the estimated coefficients on the constant and the family dummy variable obtained from Model 1 in Table 3.

${ }^{13}$ We rerun the analyses using the ratio of property, plant, and equipment over total assets as an alternative tangibility measure and including cash holdings as control variable. Overall, the findings remain qualitatively the same. To save space, the results are not reported but are available from the authors upon request.
} 
captures the distance from violation of the debt covenant (cf. Beatty, Ramesh, \& Weber, 2002; Nash, Netter, \& Poulsen, 2003): The higher the value is, the greater the slack is. ${ }^{14}$ If creditors are indeed concerned about underinvestment problems in family firms, higher coverage slack should increase firms' R\&D intensity. In addition, if Agency Problem 3 is lower in family firms, their R\&D intensity should be less sensitive to coverage slack than that of non-family firms. To test for these expectations, we adopt a two-stage approach.

In the first stage, we estimate a model to predict financial covenant slack. Following Demiroglu and James (2010), we use firm size, debt ratio, EBITDA scaled by sales, cash volatility, market-to-book ratio, the DCSI, and industry dummies as predictors. We use the minimum coverage ratio covenant as a proxy for financial covenant slack. ${ }^{15}$. Following ElGazzar and Pastena (1990), the financial covenant slack variable is defined as:

Coverage slack $=([$ Actual coverage ratio - Coverage covenant $] /$ Coverage covenant)/100,

where the actual coverage ratio is EBITDA divided by interest expenses, and the coverage covenant is the restriction imposed by the bank obtained from the DealScan database. ${ }^{16}$

In the second stage, we analyze the relation between coverage slack and R\&D. The dependent variable of the model is R\&D expenditures divided by total sales, ${ }^{17}$ which captures R\&D investment intensity (Honoré, Munari, \& de La Potterie, 2015). The main explanatory variable is the prediction of coverage slack from the first stage.

\footnotetext{
${ }^{14}$ Negative values for coverage slack represent a covenant violation. If a covenant requires a minimum ratio, the violation occurs when the firm's actual ratio is lower than that specified in the covenant.

${ }^{15}$ We use this covenant for two reasons. First, it appears more frequently in the DealScan database. Second, Demerjian and Owens (2013) show that the minimum coverage ratio covenant has only 34 definitions for 953 covenants, suggesting it is quite homogenous.

${ }^{16}$ Before defining the covenant slack variable, we make some adjustments and corrections suggested by Chava and Roberts (2008) to account for possible refinancing, overlaps, and covenant changes over time. For example, one firm has an amendment on January 15, 2004 that specifies that the minimum coverage ratio should increase gradually from 2.25 to 3.50 until the third quarter of 2005 . We use linear interpolation to estimate the quarterly ratios for each intervening quarter.

${ }^{17}$ In line with recent works (Gómez-Mejía et al., 2014; Schmid et al., 2014) and to maximize the size of the sample, we substitute the R\&D missing values with zeros. We also estimate the R\&D models using R\&D over total assets as dependent variable and the results remain qualitatively the same. To save space, the results are not reported but are available from the authors upon request.
} 
Table 4 provides the results. Model 1 shows that, while higher coverage slack affects R\&D intensity positively, this effect is less pronounced in family firms because creditors are concerned about family firms' underinvestment problem regardless of their slack level. Figure 2 shows that, as coverage slack increases, family firm investment in $R \& D$ as a proportion of sales increases by $28.32 \%$ (i.e., $[0.0145-0.0113] / 0.0113=0.2832$ ), suggesting that family firms do in fact consider coverage slack when making R\&D investments.

-----Insert Figure 2 Here-----

Performance Aspiration Gap and Forbearance. R\&D investments of family firms and their dependence on the available coverage slack might also depend on whether their performance is above or below historic aspiration levels (Chrisman \& Patel, 2012). The historic performance aspiration measure is the difference between a firm's ROA in year $t$ and its historical performance in $t-1$. To ease the interpretation of the three-way interaction term among the family variable, coverage slack, and change in performance, we create a dummy variable based on the performance difference, which equals 1 if current performance is above the historic aspiration level, and zero otherwise. Model 2 of Table 4 presents the new regression results.

Family firms with performance above aspiration levels are more likely to increase $\mathrm{R} \& \mathrm{D}$ intensity $\left(\gamma_{3}=0.001, p<0.01\right)$ and the desire to increase $\mathrm{R} \& \mathrm{D}$ is greater in family firms when performance is above aspirations and coverage slack is increasing $\left(\gamma_{4}=0.046, p<\right.$ 0.01). Therefore, the joint effect of the three variables of interest (i.e., the coefficient on the three-way interaction term) enables us to conclude that family firms invest more in R\&D when two conditions are met: (i) their performance follows an upward trend; and (ii) they have greater 'breathing room' from creditors resulting from higher coverage slack. 


\section{Robustness Tests}

We only present here a brief summary of the findings from the additional tests. Full regression results are available from the authors upon request. First, given that the DCSI measure comprises eight components, we rerun the analyses by removing from the index one component at a time to rule out the possibility that one or more of the components drive the results. The inferences are qualitatively consistent with the main results. Second, we obtain similar results when we redefine the index by removing from it the amount borrowed and the term of the loan (and including both components as predictors) and when we use the cost of private debt as a proxy for contract strictness. Third, to control for firm life cycle effects, we manually collect the founding year of each company, define an age variable, and include it in the right-hand side of the models. The main conclusions of the study remain unchanged. Fourth, we gather new data to complement the information obtained from Anderson et al. (2009), and Anderson, Reeb, et al. (2012) to check whether the founder effect explains our empirical evidence. The lower debt contract strictness of family firms and the finding that creditors do not impose stricter contracts with increases in R\&D are explained by family firms with less founder influence. ${ }^{18}$ However, both founder and non-founder family firms enjoy lower contract strictness as tangibility increases. Therefore, we conclude that the founder effect does not drive our results.

\section{DISCUSSION}

Extending past work on leverage of (González, Guzmán, Pombo, \& Trujillo, 2013; Mishra \& McConaughy, 1999) and on the different costs of debt for (Anderson et al., 2003; Boubakri \& Ghouma, 2010) family firms and applying efficient contracting theory, we find support for lower debt contract strictness in family firms. The findings indirectly suggest that, for family

\footnotetext{
${ }^{18}$ The percentage of founder family firms ranges between $21.60 \%$ and $31.20 \%$ of the family firm sample, depending on the classification criterion used.
} 
firms: (i) creditors perceive lower agency costs from shareholder-creditor agency conflicts, especially when asset tangibility is greater; and (ii) family firms avoid investments that increase risk (e.g., R\&D intensity) unless increasing coverage slack is present, whereas creditors do not increase debt contract strictness as they trust that family firms' investments do not increase to asset substitution levels.

Findings related to Hypothesis 2 extend work by Delcoure (2007) on asset tangibility and financing constraints. Given that creditors are likely to impose less strict contracts on firms with more tangible assets, higher stock of tangible assets leads to greater leniency in debt contracts in the case of family firms. Panel B of Figure 1 is counterintuitive to traditional financial economics literature (Diamond, 1984; Sharpe, 1990) that suggests that the greater information asymmetry of family firms should increase contract strictness at a faster rate than that of non-family firms when R\&D intensity is higher. A plausible explanation is that creditors may be cautious of the underinvestment problem in family firms and choose to forbear. We also advance prior research that reports that family firms prefer investing in physical assets over R\&D assets (Anderson, Duru, \& Reeb, 2012) by showing that, controlling for asset tangibility, family firms increase R\&D intensity with increasing coverage slack (Figure 2). This result extends past works on the behavioral theory of the firm that suggests that family firms change R\&D levels based on performance feedback and coverage slack (Lucas, Knoben, \& Meeus, 2015). Using information on debt covenants to get a fine-grained slack measure, we find that creditors do not perceive agency costs as increasing with higher R\&D intensity in family firms (Panel B of Figure 1); otherwise, strictness should increase with R\&D intensity.

An ancillary contribution of this work is related to the method used to test the hypotheses, which enables us to control for endogeneity and unobserved heterogeneity. The use of the system generalized method of moments estimator, in contrast to an ordinary least 
square estimator, allows us to mitigate these two problems by using instrumental variables and the integration of individual unobserved characteristics in the estimation strategy.

Chua et al. (2011) find that family involvement acts as a proxy for social capital that improves relationships with lenders and third party guarantors, thus contributing to increase the amount of debt raised by the venture. Extending their work to the public firm domain, in later stages of the firm life cycle, family involvement continues to garner lenient debt covenants. Unlike new venture firms, which face hurdles in receiving debt financing, publicly traded family firms have comparative advantage due to their governance and strategic preferences.

\section{Limitations and Future Research Directions}

The proposed framework has limitations that must be acknowledged. First, we draw on DealScan data, where covenants are coded by the data provider. Although DealScan is widely used (e.g., Bae \& Goyal, 2009; Dichev \& Skinner, 2002; Graham et al., 2008; Qian \& Strahan, 2007), the underlying negotiation process for a debt contract between the firm and the creditor remains unobserved. The panel data methodology, using the generalized method of moments, and accounting for lagged effects of debt contract strictness allow us to control for several of the unobserved characteristics in this process. Based on qualitative studies on agency theory (e.g., Shapiro, 2005), we call for future studies to assess further the dynamics of debt contract negotiation in family and non-family firms.

Second, we focus on public US firms. In addition to the limited generalizability of findings to non-US public family firms, the dynamics of debt covenant strictness are also distinct for private family firms — typically fully owned by the family — which may rely more on debt than their publicly traded counterparts. Future studies should assess whether remaining private, the founder influence, or the nature of the relationship between the family and creditors lead to variations in debt contract strictness of family firms. 
The degree of socioemotional wealth invested in the company may be higher when owners and managers have been at the helm of the business since its foundation. Therefore, future research should investigate capital structure preferences and dynamics of early-stage family firms. Debt contract strictness is also of interest in any type of lending relationship (and not only in bank loans), including financing types specific to ventures, ranging from government loans (e.g., US Small Business Administration loans) to short-term financing. In this regard, previous research finds that businesses initiated by entrepreneurs frequently evolve into family firms (Hoy \& Verser, 1994) and family firms themselves represent a substantial fraction of new entrepreneurial ventures (Morris, Williams, Allen, \& Avila, 1997).

Third, unfortunately we are unable to observe the rich family firm dynamics resulting from variations in ownership, management, and control. We caution that the dummy variables used in current and previous studies do not help assess multidimensional effects of the various family firm dimensions; however, past studies on US samples of public family firms have found strong correlations among these multidimensional factors. We call on future research to assess variations in debt preferences and in financing conditions across family firms based on the level of ownership and control, generational involvement, ownership structure, board composition, industry clock speed, and old versus new economy firms, among others. These are just some of the factors that may explain heterogeneity in the capital structure among family firms and are salient given the mixed findings on leverage in family businesses (Gottardo \& Moisello, 2016).

Fourth, debt covenants vary significantly across institutional contexts and can represent an important boundary condition for the inferences. In European or Japanese contexts, creditors have closer relationships with the firm, compared to the more arms-length relationships in the United States. Fifth, we do not distinguish between types of debt as the qualitative richness of relationality in debt is not available in archival sources. Although past 
work has construed bank debt or commercial loans as relational debt (Wang \& Thornhill, 2010), the frequency, intensity, and richness of interactions are not known. Acknowledging David et al. (2008) finding that debt is heterogeneous, future studies should qualitatively assess the nature of such relational debt. Sixth, a variety of factors can also influence the forbearance relation between coverage slack and R\&D intensity including, but not limited to, social capital of the family, relational aspects of lending, pyramidal holdings that provide indirect guarantees, and industry outlook.

While firm characteristics such as institutional ownership or external oversight by second blockholders could affect our findings, the specifications and method used enable us to mitigate the omitted variable bias. We use a panel data estimator and our empirical models are dynamic as we control for the effect of past debt contract strictness. Nonetheless, we recognize the importance of firm governance structures, such as the board of directors and the existence of multiple blockholders, and future research should explore their influence on family firm financing.

Finally, while personal guarantees are generally observed for private firms and smalland medium-sized enterprises, where family owners may leverage their social capital to provide family wealth as collateral, personal guarantees of concentrated shareholders are seldom observed for large public firms in regulated corporate debt markets. To control for possible related effects, our models include proxies for corporate collateral (i.e., firm size and asset tangibility). Unfortunately, we cannot measure personal guarantees in the available data. But their impact can be assumed stable over time and, consequently, is captured by the individual effect in the models.

\section{CONCLUSIONS}

Family business studies have focused on agency problems among principals, between family shareholders and non-family managers, and between family and non-family shareholders. We 
explore the positive aspect of family ownership on debt contract strictness in the context of shareholders-creditors agency conflict. Family firms have lower strictness in debt contracts, and increasing asset tangibility further lowers debt strictness. Creditors do not increase debt contract strictness for family firms with increasing R\&D intensity, and family firms do not increase $\mathrm{R} \& \mathrm{D}$ without increasing coverage slack. The findings extend our current understanding of debt contracts in public family firms in the United States. 


\section{REFERENCES}

Alessandri, T. M., \& Pattit, J. M. (2014). Drivers of R\&D investment: The interaction of behavioral theory and managerial incentives. Journal of Business Research, 67(2), 151-158.

Ali, A., Chen, T.-Y., \& Radhakrishnan, S. (2007). Corporate disclosures by family firms. Journal of Accounting and Economics, 44(1), 238-286.

Almeida, H., \& Campello, M. (2007). Financial constraints, asset tangibility, and corporate investment. Review of Financial Studies, 20(5), 1429-1460.

Anderson, R. C., Duru, A., \& Reeb, D. M. (2009). Founders, heirs, and corporate opacity in the United States. Journal of Financial Economics, 92(2), 205-222.

Anderson, R. C., Duru, A., \& Reeb, D. M. (2012). Investment policy in family controlled firms. Journal of Banking \& Finance, 36(6), 1744-1758.

Anderson, R. C., Mansi, S. A., \& Reeb, D. M. (2003). Founding family ownership and the agency cost of debt. Journal of Financial Economics, 68(2), 263-285.

Anderson, R. C., Reeb, D. M., \& Zhao, W. (2012). Family-Controlled firms and informed trading: Evidence from short sales. The Journal of Finance, 67(1), 351-385.

Aronoff, C., Ward, J., \& De Visscher, F. (1995). Financing transitions: Managing capital and liquidity in the family business. Marietta, GA: Business Owner Resources.

Arregle, J. L., Hitt, M. A., Sirmon, D. G., \& Very, P. (2007). The development of organizational social capital: attributes of family firms. Journal of Management Studies, 44(1), 73-95.

Aslan, H., \& Kumar, P. (2012). Strategic ownership structure and the cost of debt. Review of Financial Studies, 25(7), 2257-2299.

Bae, K.-H., \& Goyal, V. (2009). Creditor Rights, Enforcement, and Bank Loans. Journal of Finance, 64(2), 823-860.

Bagnoli, M., Liu, H.-T., \& Watts, S. G. (2011). Family firms, debtholder-shareholder agency costs and the use of covenants in private debt. Annals of Finance, 7(4), 477-509.

Beatty, A., Ramesh, K., \& Weber, J. (2002). The importance of accounting changes in debt contracts: the cost of flexibility in covenant calculations. Journal of Accounting and Economics, 33(2), 205-227.

Berrone, P., Cruz, C., Gomez-Mejia, L. R., \& Larraza-Kintana, M. (2010). Socioemotional wealth and corporate responses to institutional pressures: do family-controlled firms pollute less? Administrative Science Quarterly, 55(1), 82-113.

Bertrand, M., Johnson, S., Samphantharak, K., \& Schoar, A. (2008). Mixing family with business: A study of Thai business groups and the families behind them. Journal of financial Economics, 88(3), 466-498.

Bertrand, M., Mehta, P., \& Mullainathan, S. (2000). Ferreting out tunneling: An application to Indian business groups. Quarterly Journal of Economics, 117, 121-148.

Bianco, M., Bontempi, M. E., Golinelli, R., \& Parigi, G. (2013). Family firms' investments, uncertainty and opacity. Small Business Economics, 40(4), 1035-1058.

Block, J. H. (2012). R\&D investments in family and founder firms: An agency perspective. Journal of Business Venturing, 27(2), 248-265.

Bolton, P., \& Scharfstein, D. S. (1990). A theory of predation based on agency problems in financial contracting. American Economic Review, 93-106.

Boubakri, N., \& Ghouma, H. (2010). Control/ownership structure, creditor rights protection, and the cost of debt financing: International evidence. Journal of Banking \& Finance, 34(10), 2481-2499.

Burkart, M., Panunzi, F., \& Shleifer, A. (2003). Family firms. The Journal of Finance, 58(5), 2167-2202. 
Campello, M., \& Giambona, E. (2011). Capital structure and the redeployability of tangible assets: Tinbergen Institute Discussion Papero. Document Number)

Carney, M. (2005). Corporate governance and competitive advantage in family-controlled firms. Entrepreneurship theory and practice, 29(3), 249-265.

Casson, M. (1999). The economics of the family firm. Scandinavian Economic History Review, 47(1), 10-23.

Céspedes, J., González, M., \& Molina, C. A. (2010). Ownership and capital structure in Latin America. Journal of Business Research, 63(3), 248-254.

Chava, S., Kumar, P., \& Warga, A. (2010). Managerial agency and bond covenants. Review of Financial Studies, 23(3), 1120-1148.

Chava, S., \& Roberts, M. R. (2008). How does financing impact investment? The role of debt covenants. Journal of Finance, 63(5), 2085-2121.

Chen, H.-L., \& Hsu, W.-T. (2009). Family ownership, board independence, and R\&D investment. Family Business Review.

Chrisman, J. J., \& Patel, P. C. (2012). Variations in R\&D investments of family and nonfamily firms: behavioral agency and myopic loss aversion perspectives. Academy of Management Journal, 55(4), 976-997.

Chrisman, J. J., Sharma, P., Steier, L. P., \& Chua, J. H. (2013). The influence of family goals, governance, and resources on firm outcomes. Entrepreneurship Theory and Practice, $37(6), 1249-1261$.

Chua, J. H., Chrisman, J. J., Kellermanns, F., \& Wu, Z. (2011). Family involvement and new venture debt financing. Journal of Business Venturing, 26(4), 472-488.

Corbetta, G., \& Salvato, C. (2004). Self-serving or self-actualizing? Models of man and agency costs in different types of family firms: A commentary on "Comparing the agency costs of family and non-family firms: Conceptual issues and exploratory evidence". Entrepreneurship Theory and Practice, 28(4), 355-362.

Croci, E., Doukas, J. A., \& Gonenc, H. (2011). Family control and financing decisions. European Financial Management, 17(5), 860-897.

David, P., O'Brien, J. P., \& Yoshikawa, T. (2008). The implications of debt heterogeneity for R\&D investment and firm performance. Academy of Management Journal, 51(1), $165-181$.

Delcoure, N. (2007). The determinants of capital structure in transitional economies. International Review of Economics \& Finance, 16(3), 400-415.

Demerjian, P. R. (2011). Accounting standards and debt covenants: Has the "balance sheet approach" led to a decline in the use of balance sheet covenants? Journal of Accounting and Economics, 52(2), 178-202.

Demerjian, P. R., \& Owens, E. L. (2013). Measuring financial covenant strictness in private debt contracts. Available at SSRN 2232880.

Demiroglu, C., \& James, C. M. (2010). The information content of bank loan covenants. Review of Financial Studies, hhq054.

Diamond, D. W. (1984). Financial intermediation and delegated monitoring. The Review of Economic Studies, 51(3), 393-414.

Dichev, I. D., \& Skinner, D. J. (2002). Large-sample evidence on the debt covenant hypothesis. Journal of accounting research, 40(4), 1091-1123.

Duran, P., Kammerlander, N., Van Essen, M., \& Zellweger, T. (2015). Doing more with less: Innovation input and output in family firms. Academy of Management Journal, amj. 2014.0424.

El-Gazzar, S., \& Pastena, V. (1990). Negotiated accounting rules in private financial contracts. Journal of Accounting and Economics, 12(4), 381-396. 
Emanuel, D., Wong, J., \& Wong, N. (2003). Efficient contracting and accounting. Accounting \& Finance, 43(2), 149-166.

Erbetta, F., Menozzi, A., Corbetta, G., \& Fraquelli, G. (2013). Assessing family firm performance using frontier analysis techniques: Evidence from Italian manufacturing industries. Journal of Family Business Strategy, 4(2), 106-117.

Fehr, E., Brown, M., \& Zehnder, C. (2009). On reputation: A microfoundation of contract enforcement and price rigidity. The Economic Journal, 119(536), 333-353.

Frankel, R., Seethamraju, C., \& Zach, T. (2008). GAAP goodwill and debt contracting efficiency: evidence from net-worth covenants. Review of Accounting Studies, 13(1), 87-118.

Friedman, E., Johnson, S., \& Mitton, T. (2003). Propping and tunneling. Journal of Comparative Economics, 31(4), 732-750.

Gedajlovic, E., Carney, M., Chrisman, J. J., \& Kellermanns, F. W. (2012). The adolescence of family firm research taking stock and planning for the future. Journal of Management, 38(4), 1010-1037.

Gigler, F., Kanodia, C., Sapra, H., \& Venugopalan, R. (2009). Accounting conservatism and the efficiency of debt contracts. Journal of Accounting Research, 47(3), 767-797.

Gomez-Mejia, L. R., Cruz, C., Berrone, P., \& De Castro, J. (2011). The bind that ties: socioemotional wealth preservation in family firms. Academy of Management Annals, 5(1), 653-707.

Gómez-Mejía, L. R., Haynes, K. T., Núñez-Nickel, M., Jacobson, K. J., \& Moyano-Fuentes, J. (2007). Socioemotional wealth and business risks in family-controlled firms: Evidence from Spanish olive oil mills. Administrative Science Quarterly, 52(1), 106137.

Gompers, P. A. (1995). Optimal investment, monitoring, and the staging of venture capital. Journal of Finance, 50(5), 1461-1489.

González, M., Guzmán, A., Pombo, C., \& Trujillo, M.-A. (2013). Family firms and debt: Risk aversion versus risk of losing control. Journal of Business Research, 66(11), 2308-2320.

Gottardo, P., \& Moisello, A. M. (2016). The impact of family control and influence on leverage. European Journal of Economics, Finance and Administrative Sciences (87), 5-24.

Graham, J. R., Li, S., \& Qiu, J. (2008). Corporate misreporting and bank loan contracting. Journal of Financial Economics, 89(1), 44-61.

Hall, T. W. (2012). The collateral channel: Evidence on leverage and asset tangibility. Journal of Corporate Finance, 18(3), 570-583.

Hart, O., \& Moore, J. (1994). Debt and seniority: An analysis of the role of hard claims in constraining management: National Bureau of Economic Researcho. Document Number)

Holthausen, R. W. (1990). Accounting method choice: Opportunistic behavior, efficient contracting, and information perspectives. Journal of Accounting and Economics, 12(1-3), 207-218.

Holthausen, R. W., \& Leftwich, R. W. (1983). The economic consequences of accounting choice implications of costly contracting and monitoring. Journal of Accounting and Economics, 5, 77-117.

Honoré, F., Munari, F., \& de La Potterie, B. v. P. (2015). Corporate governance practices and companies' R\&D intensity: Evidence from European countries. Research Policy, 44(2), 533-543.

Hoy, F., \& Verser, T. G. (1994). Emerging business, emerging field: Entrepreneurship and the family firm. Entrepreneurship: Theory and Practice, 19(1), 9-24. 
Jain, B. A., \& Shao, Y. (2014). Family involvement and post-IPO investment policy. Family Business Review, 27(4), 287-306.

Jensen, M. C., \& Meckling, W. H. (1976). Theory of the firm: Managerial behavior, agency costs and ownership structure. Journal of Financial Economics, 3(4), 305-360.

Jiang, G., Lee, C. M., \& Yue, H. (2010). Tunneling through intercorporate loans: The China experience. Journal of Financial Economics, 98(1), 1-20.

King, M. R., \& Santor, E. (2008). Family values: Ownership structure, performance and capital structure of Canadian firms. Journal of Banking \& Finance, 32(11), 24232432.

Kothari, S., Laguerre, T. E., \& Leone, A. J. (2002). Capitalization versus expensing: Evidence on the uncertainty of future earnings from capital expenditures versus R\&D outlays. Review of accounting Studies, 7(4), 355-382.

Lang, L., Ofek, E., \& Stulz, R. (1996). Leverage, investment, and firm growth. Journal of Financial Economics, 40(1), 3-29.

Lee, J. (2006). Family firm performance: Further evidence. Family business review, 19(2), 103-114.

Lehmann, E., Warning, S., \& Weigand, J. (2004). Governance structures, multidimensional efficiency and firm profitability. Journal of Management and Governance, 8(3), 279304.

Lin, C., Ma, Y., Malatesta, P., \& Xuan, Y. (2011). Ownership structure and the cost of corporate borrowing. Journal of Financial Economics, 100(1), 1-23.

Lin, Y.-M., \& Shen, C.-A. (2015). Family firms' credit rating, idiosyncratic risk, and earnings management. Journal of Business Research, 68(4), 872-877.

Lucas, G. J., Knoben, J., \& Meeus, M. T. (2015). Contradictory yet Coherent? Inconsistency in Performance Feedback and R\&D Investment Change. Journal of Management, 0149206315584821.

Mather, P., \& Peirson, G. (2006). Financial covenants in the markets for public and private debt. Accounting \& Finance, 46(2), 285-307.

McConaughy, D. L. (1999). Is the cost of capital different for family firms? Family Business Review, 12(4), 353-360.

McConaughy, D. L., Walker, M. C., Henderson, G. V., \& Mishra, C. S. (1998). Founding family controlled firms: Efficiency and value. Review of Financial economics, 7(1), 119.

Mishra, C. S., \& McConaughy, D. L. (1999). Founding family control and capital structure: The risk of loss of control and the aversion to debt. Entrepreneurship Theory and Practice, 23(4), 53-53.

Morris, M. H., Williams, R. O., Allen, J. A., \& Avila, R. A. (1997). Correlates of success in family business transitions. Journal of business venturing, 12(5), 385-401.

Myers, S. C. (1977). Determinants of corporate borrowing. Journal of Financial Economics, $5(2), 147-175$.

Nash, R. C., Netter, J. M., \& Poulsen, A. B. (2003). Determinants of contractual relations between shareholders and bondholders: investment opportunities and restrictive covenants. Journal of Corporate Finance, 9(2), 201-232.

Nini, G., Smith, D. C., \& Sufi, A. (2012). Creditor control rights, corporate governance, and firm value. Review of Financial Studies, 25(6), 1713-1761.

O'brien, J. P. (2003). The capital structure implications of pursuing a strategy of innovation. Strategic Management Journal, 24(5), 415-431.

Pérez-González, F. (2006). Inherited control and firm performance. The American economic review, 96(5), 1559-1588. 
Pindado, J., \& Requejo, I. (2015). Family business performance from a governance perspective: A review of empirical research. International Journal of Management Reviews, 17(3), 279-311.

Poutziouris, P. Z. (2002). The financial affairs of smaller family companies. Understanding the small family business, 111-126.

Prencipe, A., Markarian, G., \& Pozza, L. (2008). Earnings management in family firms: Evidence from R\&D cost capitalization in Italy. Family Business Review, 21(1), 7188.

Qian, J., \& Strahan, P. E. (2007). How laws and institutions shape financial contracts: The case of bank loans. Journal of Finance, 62(6), 2803-2834.

Romano, C. A., Tanewski, G. A., \& Smyrnios, K. X. (2001). Capital structure decision making: A model for family business. Journal of business venturing, 16(3), 285-310.

Shapiro, S. P. (2005). Agency theory. Annual Review of Sociology, 263-284.

Sharpe, S. A. (1990). Asymmetric information, bank lending, and implicit contracts: A stylized model of customer relationships. Journal of Finance, 45(4), 1069-1087.

Shyu, Y. W., \& Lee, C. I. (2009). Excess Control Rights and Debt Maturity Structure in Family-Controlled Firms. Corporate Governance: An International Review, 17(5), 611-628.

Sirmon, D. G., \& Hitt, M. A. (2003). Managing resources: linking unique resources, management, and wealth creation in family firms. Entrepreneurship Theory and Practice, 27(4), 339-358.

Smith, C. W., \& Warner, J. B. (1979). On financial contracting: An analysis of bond covenants. Journal of Financial Economics, 7(2), 117-161.

Uzzi, B. (1999). Embeddedness in the making of financial capital: How social relations and networks benefit firms seeking financing. American Sociological Review, 64(4), 481505.

Villalonga, B., Amit, R., Trujillo, M.-A., \& Guzmán, A. (2015). Governance of Family Firms. Annual Review of Financial Economics, 7, 635-654.

Wang, C., \& Williamson, S. D. (1998). Debt contracts and financial intermediation with costly screening. Canadian Journal of Economics, 31(3), 573-595.

Wang, D. (2006). Founding family ownership and earnings quality. Journal of Accounting Research, 44(3), 619-656.

Wang, T., \& Thornhill, S. (2010). R\&D investment and financing choices: A comprehensive perspective. Research Policy, 39(9), 1148-1159.

Wen, Y., Rwegasira, K., \& Bilderbeek, J. (2002). Corporate governance and capital structure decisions of the Chinese listed firms. Corporate Governance: An International Review, 10(2), 75-83.

Whittred, G., \& Zimmer, I. (1986). Accounting information in the market for debt. Accounting \& Finance, 26(2), 19-33.

Williamson, O. E. (1988). Corporate finance and corporate governance. Journal of Finance, 43(3), 567-591.

Wiwattanakantang, Y. (1999). An empirical study on the determinants of the capital structure of Thai firms. Pacific-Basin Finance Journal, 7(3), 371-403. 
Table 1

Definitions and Summary Statistics of DCSI Components and Variables Operationalizations

Panel A. Definitions of debt contract strictness index (DCSI) components

Component $\quad$ Explanation and definition of dummy variables

Amount borrowed The amount of money that has been lent by the debtholder. Equals 1 if the amount borrowed is higher than the sample median, zero otherwise.

If contract is secured The contract is secured when there is a collateral (the borrower pledges some assets). Equals 1 if the value is higher than the median, zero otherwise.

If it is revolver loan Revolver loans allow the company to choose how often they want to withdraw from the loan and at what time intervals, granting the firm more flexibility than other loans. Equals 1 if the value is lower than the median, zero otherwise.

Distribution method Syndicated loan is one that is provided and administrated by a group of lenders. Equals 1 if the value is higher than the median, zero otherwise.

Price of debt Describes the amount a borrower pays in basis points over LIBOR for each dollar drawn down. Equals 1 if the value is higher than the median, zero otherwise.

Number of lenders Number of debtholders. Equals 1 if the value is higher than the median, zero otherwise. Maturity Number of days to give back the loan. Equals 1 if the value is lower than the median, zero otherwise.

Number of covenants Number of covenants. Equals 1 if the value is higher than the median, zero otherwise. Panel B. Summary Statistics

\begin{tabular}{lcccc}
\hline Component & Mean & SD & Within \\
\hline Amount borrowed & 0.4911 & 0.4999 & 0.4323 & 0.2701 \\
If contract is secured & 0.4577 & 0.4982 & 0.4430 & 0.2486 \\
If it is revolver loan & 0.5050 & 0.5000 & 0.4126 & 0.3122 \\
Distribution method & 0.7581 & 0.4283 & 0.3803 & 0.2231 \\
Price of debt & 0.4985 & 0.5000 & 0.4320 & 0.2739 \\
Number of lenders & 0.5009 & 0.5000 & 0.4260 & 0.2929 \\
Maturity & 0.498 & 0.5000 & 0.4134 & 0.3041 \\
Number of covenants & 0.1500 & 0.3571 & 0.3433 & 0.1468 \\
DCSI & 3.8593 & 1.3928 & 1.2096 & 0.7699
\end{tabular}

Panel C. Variable Operationalization

\begin{tabular}{|c|c|c|}
\hline Dependent variable & $\begin{array}{l}\text { Main analysis or } \\
\text { robustness }\end{array}$ & Description \\
\hline $\begin{array}{l}\text { Debt Contract } \\
\text { Strictness Index } \\
\text { (DCSI) }\end{array}$ & Main analysis & $\begin{array}{l}\text { Index composed by eight components (explained in Table } 1 \text { ), which } \\
\text { ranges from zero to } 8 \text {. For each component, we give the value of } 1 \text { if } \\
\text { the characteristic is tight, and zero otherwise, and then we sum the } \\
\text { eight values. }\end{array}$ \\
\hline Family firm dummy & All analyses & $\begin{array}{l}\text { Takes the value of } 1 \text { if the company is a family firm, following the } \\
\text { criteria of Anderson et al. ( } 2009 \text { ) and Anderson et al. ( } 2012 \mathrm{~b}) \text {, and } \\
\text { zero otherwise. These authors define family firms as those where the } \\
\text { family (founders or founders' descendants) continues to maintain a } \\
5 \% \text { or greater ownership stake. }\end{array}$ \\
\hline \multicolumn{3}{|l|}{ Moderator variables } \\
\hline Asset tangibility & Main analysis & $\begin{array}{l}\text { We follow Almeida and Campello }(2007) \text { and compute asset } \\
\text { tangibility as }(0.715 * \text { accounts receivables }+0.547 * \text { inventory }+ \\
0.535 * \text { PP\&ENet }+ \text { cash }) \text { scaled by total assets }\end{array}$ \\
\hline R\&D/Sales & Main analysis & R\&D expenditures scaled by the firm's total sales \\
\hline R\&D/Total assets & Main analysis & R\&D expenditures scaled by the firm's total assets \\
\hline \multicolumn{3}{|l|}{ Control variables } \\
\hline ROA & All analyses & Net income scaled by total assets \\
\hline Size & All analyses & Log of total sales \\
\hline Debt & All analyses & Long term debt scaled by total assets \\
\hline Dividends & All analyses & Cash dividends scaled by total assets \\
\hline Risk & All analyses & St. dev. of the firm's stock returns during the quarter \\
\hline Market-to-book & All analyses & (Market value of equity + total debt) scaled by total assets \\
\hline $\begin{array}{l}\text { Additional variable: } \\
\text { Coverage Slack }\end{array}$ & Robustness & $\begin{array}{l}\text { ([Actual coverage ratio - Coverage covenant }] / \text { Coverage } \\
\text { covenant }) / 100\end{array}$ \\
\hline
\end{tabular}


Table 2

Descriptive Analyses: Main Summary Statistics and Difference of Mean Tests

Panel A. Summary statistics and correlation matrix

\begin{tabular}{|c|c|c|c|c|c|c|c|c|c|c|c|c|c|c|c|}
\hline Variables & Mean & SD & Min & Max & 1 & 2 & 3 & 4 & 5 & 6 & 7 & 8 & 9 & 10 & 11 \\
\hline 1. DCSI & 3.8593 & 1.3927 & .0000 & 8.0000 & & & & & & & & & & & \\
\hline 2. Family & .2767 & .4474 & .0000 & 1.0000 & $-.0586^{* * *}$ & & & & & & & & & & \\
\hline 3. Asset tangibility & .3928 & .1359 & .0329 & .8175 & $-.1821 * * *$ & $-.1196 * * *$ & & & & & & & & & \\
\hline 4. R\&D/Sales & .0009 & .0256 & .0000 & 1.7053 & .0009 & $-.0176 * *$ & $-.0275 * * *$ & & & & & & & & \\
\hline 5. R\&D/Total assets & .0001 & .0029 & .0000 & .1598 & -.0072 & $-.0148 *$ & $-.0223 * * *$ & $.9198 * * *$ & & & & & & & \\
\hline 6. Coverage slack & .0316 & .0573 & -.0422 & .9485 & $-.1887 * * *$ & $.0144 *$ & $.1897 * * *$ & $.0342 * * *$ & $.0248 * * *$ & & & & & & \\
\hline 7. ROA & .0061 & .0442 & -.7013 & 1.8991 & $-.0854 * * *$ & $-.0404 * * *$ & $.0632 * * *$ & $-.0599 * * *$ & $-.0664 * * *$ & $.1524 * * *$ & & & & & \\
\hline 8. Size & 5.9095 & 1.2494 & 1.4002 & 10.2757 & $.1080 * * *$ & $-.2389 * * *$ & $.0418 * * *$ & .0064 & .0083 & $.0296 * * *$ & $.1010 * * *$ & & & & \\
\hline 9. Debt & .2876 & .1786 & .0000 & .9484 & $.2295 * * *$ & $.0420 * * *$ & $-.2337 * * *$ & -.0056 & -.0133 & $-.4390 * * *$ & $-.1355^{* * *}$ & $-.1534 * * *$ & & & \\
\hline 10. Dividends & .0002 & .0038 & .0000 & .4290 & $.0174 * *$ & -.0082 & .0105 & .0003 & -.0000 & $-.0244 * * *$ & $-.0273 * * *$ & $-.0408 * * *$ & $.0370^{* * *}$ & & \\
\hline 11. Risk & 1.8334 & 1.6962 & .0000 & 15.4935 & $-.0687 * * *$ & $-.0230 * * *$ & .0626 & -.0030 & -.0063 & $.1285 * * *$ & $.1062 * * *$ & $.1281 * * *$ & $-.1296 * * *$ & $-.0266 * * *$ & \\
\hline 12. Market-to-book & 1.2429 & .6576 & .0067 & 5.9407 & $-.1569 * * *$ & $-.0623 * * *$ & $.0247 * * *$ & $.0239 * * *$ & $.0425 * * *$ & $.3154 * * *$ & $.2382 * * *$ & $.0250 * * *$ & $-.0934 * * *$ & $-.0317 * * *$ & $.1955^{* * *}$ \\
\hline
\end{tabular}

Panel B. Differences of mean tests of main variables: Family versus non-family firms

\begin{tabular}{|c|c|c|c|c|}
\hline & All firms & Family & Non-family & $\begin{array}{c}t \text {-statistic } \\
\text { (Non-family-Family) }\end{array}$ \\
\hline No. Obs. & 14,904 & 4,125 & 10,779 & \\
\hline DCSI & 3.8593 & 3.7272 & 3.9098 & $7.1711 * * *$ \\
\hline Asset tangibility & 0.3928 & 0.3666 & 0.4029 & $14.7041 * * *$ \\
\hline R\&D/Sales & 0.0009 & 0.0002 & 0.0012 & $2.1469 * *$ \\
\hline $\mathrm{R} \& \mathrm{D} /$ Total assets & 0.0001 & 0.0000 & 0.0001 & $1.8128^{* *}$ \\
\hline Coverage slack & 0.0316 & 0.0330 & 0.0311 & $-1.7634^{* *}$ \\
\hline Coverage ratio & 12.2778 & 11.8851 & 12.4281 & $1.6701 * *$ \\
\hline Coverage covenant & 2.8096 & 2.6504 & 2.8705 & $13.5290 * * *$ \\
\hline \multicolumn{5}{|c|}{ Panel C. Differences of mean tests of other variables: Family versus non-family firms } \\
\hline No. Obs. & 14,904 & 4,125 & 10,779 & \\
\hline ROA & 0.0061 & 0.0032 & 0.0072 & $4.9354 * * *$ \\
\hline Size & 5.9095 & 5.4271 & 6.0942 & $30.0301 * * *$ \\
\hline Debt & 0.2876 & 0.2998 & 0.2830 & $-5.1318 * * *$ \\
\hline Dividends & 0.0002 & 0.0001 & 0.0002 & 1.0059 \\
\hline Risk & 1.8334 & 1.7702 & 1.8576 & $2.8140 * * *$ \\
\hline Market-to-book & 1.2429 & 1.1767 & 1.2682 & $7.6180 * * *$ \\
\hline
\end{tabular}

The percentage of family firms in the sample is $27.68 \%{ }^{* * *} p<0.01 . * * p<0.05 . * p<0.10$. 
Table 3

Debt Contract Strictness Index and Family Firms

\begin{tabular}{|c|c|c|c|c|}
\hline & (1) & (2) & (3) & $(4)$ \\
\hline Dependent variable: & DCSI & DCSI & DCSI & DCSI \\
\hline \multicolumn{5}{|l|}{ Controls: } \\
\hline \multirow[t]{2}{*}{ DCSI $(t-1)$} & $0.896 * * *$ & $0.897 * * *$ & $0.896 * * *$ & $0.897 * * *$ \\
\hline & $(0.000)$ & $(0.000)$ & $(0.000)$ & $(0.000)$ \\
\hline \multirow[t]{2}{*}{ ROA } & $-0.196 * * *$ & $-0.189 * * *$ & $-0.195 * * *$ & $-0.195 * * *$ \\
\hline & $(0.005)$ & $(0.005)$ & $(0.008)$ & $(0.006)$ \\
\hline \multirow[t]{2}{*}{ Size } & $0.019 * * *$ & $0.018 * * *$ & $0.020 * * *$ & $0.019 * * *$ \\
\hline & $(0.000)$ & $(0.000)$ & $(0.000)$ & $(0.000)$ \\
\hline \multirow[t]{2}{*}{ Debt } & $0.115 * * *$ & $0.121 * * *$ & $0.118 * * *$ & $0.125 * * *$ \\
\hline & $(0.003)$ & $(0.002)$ & $(0.002)$ & $(0.003)$ \\
\hline \multirow[t]{2}{*}{ Dividends } & $-0.080 *$ & $-0.094 *$ & -0.024 & $-0.126 * *$ \\
\hline & $(0.043)$ & $(0.049)$ & $(0.034)$ & $(0.050)$ \\
\hline \multirow[t]{2}{*}{ Risk } & $-0.002 * * *$ & $-0.003 * * *$ & $-0.002 * * *$ & $-0.003 * * *$ \\
\hline & $(0.000)$ & $(0.000)$ & $(0.000)$ & $(0.000)$ \\
\hline \multirow[t]{2}{*}{ Market-to-book } & $-0.051 * * *$ & $-0.048 * * *$ & $-0.049 * * *$ & $-0.048 * * *$ \\
\hline & $(0.000)$ & $(0.000)$ & $(0.000)$ & $(0.000)$ \\
\hline \multicolumn{5}{|l|}{ Independent variables: } \\
\hline \multirow[t]{2}{*}{ Family } & $-0.024 * * *$ & $0.095 * * *$ & $-0.023 * * *$ & $0.095 * * *$ \\
\hline & $(0.001)$ & $(0.006)$ & $(0.001)$ & $(0.005)$ \\
\hline \multirow[t]{2}{*}{ Asset tangibility } & $-0.079 * * *$ & 0.005 & $-0.092 * * *$ & $0.010 * *$ \\
\hline & $(0.005)$ & $(0.006)$ & $(0.004)$ & $(0.004)$ \\
\hline \multirow[t]{2}{*}{ R\&D/Sales } & $0.573 * * *$ & $0.588 * * *$ & $0.613 * * *$ & $0.630 * * *$ \\
\hline & $(0.008)$ & $(0.009)$ & $(0.008)$ & $(0.009)$ \\
\hline \multicolumn{5}{|l|}{ Interaction effects: } \\
\hline \multirow[t]{2}{*}{ Family * Asset tangibility } & & $-0.309 * * *$ & & $-0.302 * * *$ \\
\hline & & $(0.014)$ & & $(0.012)$ \\
\hline \multirow[t]{2}{*}{ Family $*$ R\&D/Sales } & & & $-0.633 * * *$ & $-0.643 * * *$ \\
\hline & & & $(0.036)$ & $(0.035)$ \\
\hline \multirow[t]{2}{*}{ Cons. } & $0.385 * * *$ & $0.350 * * *$ & $0.386^{* * *}$ & $0.343 * * *$ \\
\hline & $(0.004)$ & $(0.004)$ & $(0.004)$ & $(0.004)$ \\
\hline \multicolumn{5}{|l|}{ Specification tests: } \\
\hline$z_{1}$ & $2,700,000(10)$ & $6,800,000(11)$ & $4,700,000(11)$ & $2,900,000(12)$ \\
\hline$z_{2}$ & $9,809.09(8)$ & $5,548.67(8)$ & $7,548.11(8)$ & $5,008.23$ \\
\hline$z_{3}$ & $878.21(7)$ & $533.72(7)$ & $1,175.71(7)$ & $807.54(7)$ \\
\hline$m_{1}$ & -16.45 & -16.45 & -16.44 & -16.45 \\
\hline$m_{2}$ & -0.30 & -0.31 & -0.30 & -0.32 \\
\hline Hansen ( $p$-value) & $(1.000)$ & $(1.000)$ & $(1.000)$ & $(1.000)$ \\
\hline
\end{tabular}

Notes: System GMM regression results. Lags from $t-1$ to $t-3$ are used as instruments in the equations in differences for all the right-hand side variables (except for the lagged dependent variable, DCSI, which is assigned lags from $t-2$ to $t-4$ ) and only one instrument is used for the equations in levels. All models include time and industry dummies. Standard errors are in parentheses. $N=14,904$.

${ }^{* * *} p<0.01 .{ }^{* *} p<0.05 .{ }^{*} p<0.10$. 
Table 4

Effect of Coverage Slack on R\&D Intensity across Family and Non-Family Firms

\begin{tabular}{|c|c|c|}
\hline & $(1)$ & $(2)$ \\
\hline Dependent variable: & $R \& D$ Intensity & $R \& D$ Intensity \\
\hline \multicolumn{3}{|l|}{ Controls: } \\
\hline $\mathrm{R} \& \mathrm{D} /$ Sales $(t-1)$ & $\begin{array}{c}0.159 * * * \\
(0.000)\end{array}$ & $\begin{array}{c}0.161 * * * \\
(0.000)\end{array}$ \\
\hline ROA & $\begin{array}{c}-0.036^{* * *} \\
(0.000)\end{array}$ & $\begin{array}{c}-0.034 * * * \\
(0.001)\end{array}$ \\
\hline Size & $\begin{array}{c}0.000 * * * \\
(0.000)\end{array}$ & $\begin{array}{c}0.000 * * \\
(0.000)\end{array}$ \\
\hline Debt & $\begin{array}{c}0.001 * * * \\
(0.000)\end{array}$ & $\begin{array}{c}0.001 * * * \\
(0.000)\end{array}$ \\
\hline Dividends & $\begin{array}{c}0.015 * * * \\
(0.000)\end{array}$ & $\begin{array}{c}0.012 * * * \\
(0.002)\end{array}$ \\
\hline Risk & $\begin{array}{l}-0.000 * * * \\
(0.000)\end{array}$ & $\begin{array}{c}-0.000 * * * \\
(0.000)\end{array}$ \\
\hline Market-to-book & $\begin{array}{c}-0.000^{* *} \\
(0.000)\end{array}$ & $\begin{array}{c}0.000 * * * \\
(0.000)\end{array}$ \\
\hline Asset tangibility & $\begin{array}{l}-0.034 * * * \\
(0.000)\end{array}$ & $\begin{array}{l}-0.024 * * * \\
(0.000)\end{array}$ \\
\hline \multicolumn{3}{|l|}{ Independent variables: } \\
\hline Family & $\begin{array}{c}-0.001 * * * \\
(0.000)\end{array}$ & $\begin{array}{c}-0.001 * * * \\
(0.000)\end{array}$ \\
\hline Coverage slack & $\begin{array}{c}0.045^{* * *} \\
(0.000)\end{array}$ & $\begin{array}{c}0.059 * * * \\
(0.001)\end{array}$ \\
\hline Performance aspiration gap & & $\begin{array}{l}-0.000 \\
(0.000)\end{array}$ \\
\hline \multicolumn{3}{|l|}{ Interaction effects: } \\
\hline Family $*$ Coverage slack & $\begin{array}{c}-0.017 * * * \\
(0.000)\end{array}$ & $\begin{array}{l}-0.041 * * * \\
(0.001)\end{array}$ \\
\hline Performance aspiration gap * & & $-0.047 * * *$ \\
\hline Coverage slack & & $(0.001)$ \\
\hline $\begin{array}{l}\text { Family * Performance } \\
\text { aspiration gap }\end{array}$ & & $\begin{array}{c}0.001 * * * \\
(0.000)\end{array}$ \\
\hline Family $*$ Coverage slack $*$ & & $0.046 * * *$ \\
\hline Performance aspiration gap & & $(0.001)$ \\
\hline Cons. & $\begin{array}{c}0.013 * * * \\
(0.000)\end{array}$ & $\begin{array}{c}0.009 * * * \\
(0.000)\end{array}$ \\
\hline \multicolumn{3}{|l|}{ Specification tests: } \\
\hline$z_{1}$ & $420,000(11)$ & $40,857.46(15)$ \\
\hline$z_{2}$ & $2,580.72(8)$ & $735.31(8)$ \\
\hline$z_{3}$ & $884.96(7)$ & $625.89(7)$ \\
\hline$m_{1}$ & -1.89 & -1.89 \\
\hline$m_{2}$ & -0.73 & -0.74 \\
\hline Hansen ( $p$-value) & $(1.000)$ & $(1.000)$ \\
\hline
\end{tabular}

Notes: System GMM regression results. Lags from $t^{-1}$ to $t-3$ are used as instruments in the equations in differences for all the right-hand side variables (except for the lagged dependent variable, DCSI, which is assigned lags from $t-2$ to $t-4$ ) and only one instrument is used for the equations in levels. All models include time and industry dummies. Standard errors are in parentheses. $N=14,904$.

$* * * p<0.01 . * * p<0.05 . * p<0.10$. 
FIGURE 1

Moderation Effects in DCSI Model

Panel A. Moderation effects of asset tangibility

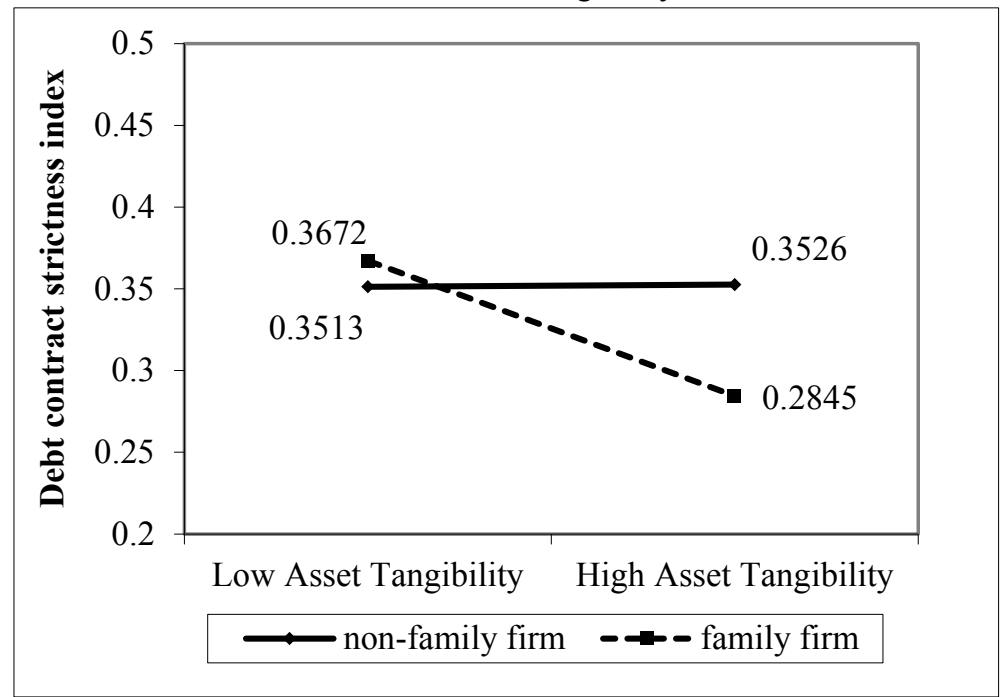

Panel B. Moderation effects of R\&D intensity

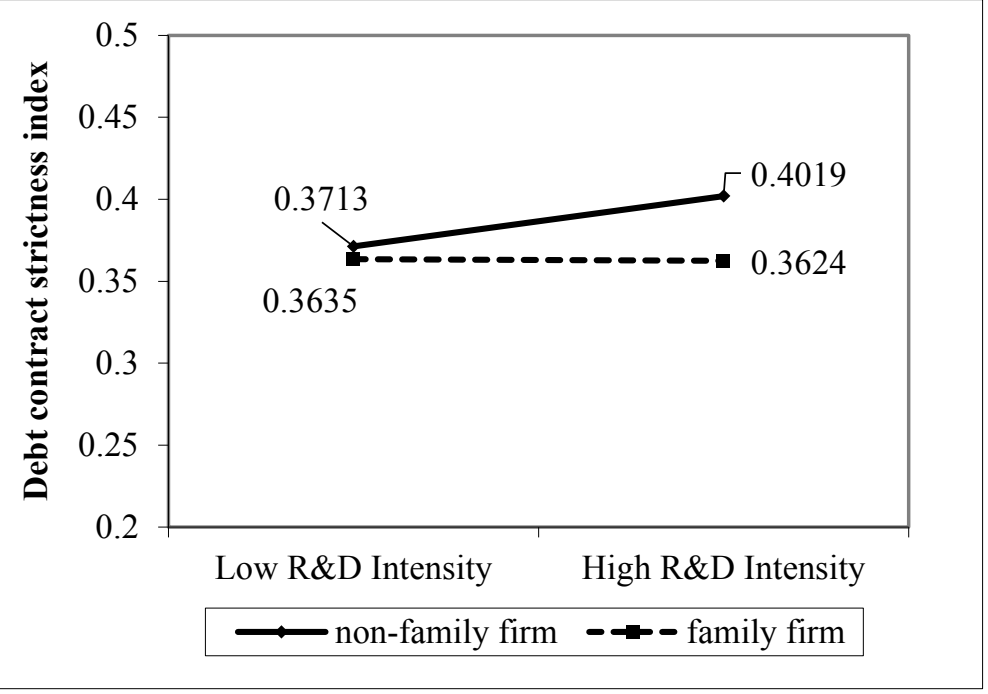

FIGURE 2

Moderation Effect of Coverage Slack in R\&D Model

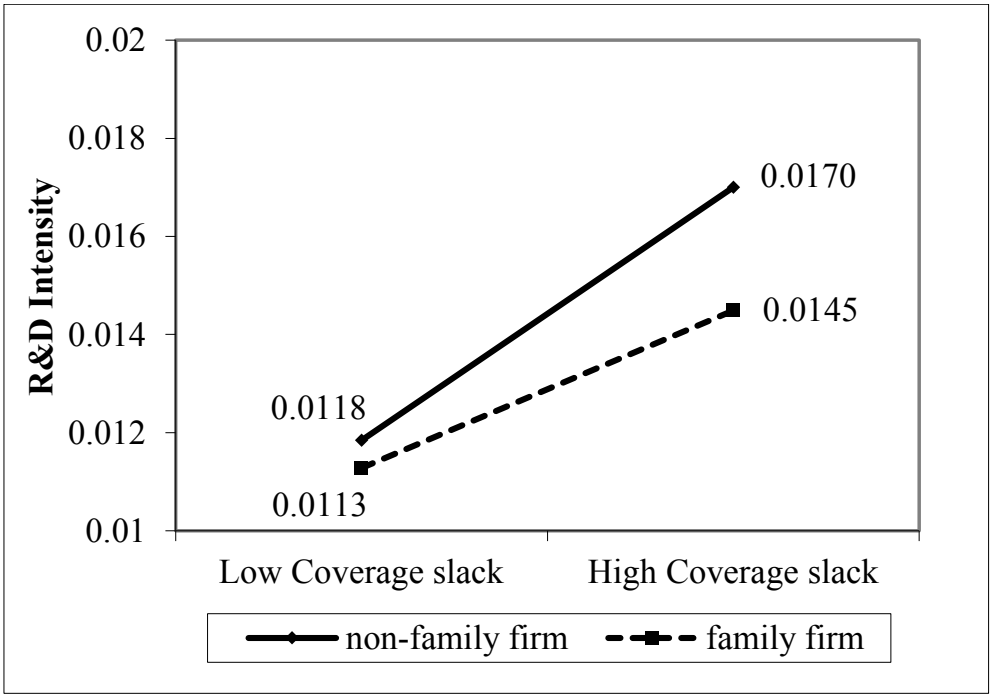

